\title{
H. Martirosyan
}

Leiden University

\section{THE DEVELOPMENT OF THE CLASSICAL ARMENIAN AORIST IN MODERN DIALECTS}

This paper aims to present a sketch on the development of the Classical Armenian aorist in the dialects with particular attention on Hamšen, Aramo, and other peripheral dialects, as well as some related issues, such as the aorist augment $e$ - and the vowel $-a$ - of the first person plural endings in the aorist and imperfect paradigms ${ }^{1}$.

\section{Classical Armenian aorist}

The active endings are: $-i,-e r$, zero, $-a k^{\star},-\bar{e} / i k^{\star},-i n ; 3 \mathrm{sg}$. augment $e$-when the stem is monosyllabic.

Table 1. The aorist paradigms of Classical Armenian

\begin{tabular}{|c|c|c|c|c|}
\hline & $\begin{array}{l}\text { lam } \\
\text { 'to weep, cry' }\end{array}$ & $\begin{array}{l}\text { berem } \\
\text { 'to bring' }\end{array}$ & $\begin{array}{l}\text { sirem } \\
\text { 'to love' }\end{array}$ & $\begin{array}{l}\text { t'olum } \\
\text { 'to let, leave' }\end{array}$ \\
\hline $1 \mathrm{sg}$. & $l a c{ }^{\prime} i$ & beri & sirec $^{\prime} i$ & t'oti \\
\hline $2 \mathrm{sg}$. & lac'er & berer & sirec'er $^{\prime}$ & t'oter \\
\hline $3 \mathrm{sg}$. & $e-l a c^{\prime}$ & $e$-ber & sireac" & $e-t^{\prime} o t$ \\
\hline $1 \mathrm{pl}$. & $l a c^{\prime} a k^{\prime}$ & berak' & $\operatorname{sirec}^{\prime} a k^{\prime}$ & t'otak' \\
\hline $2 \mathrm{pl}$. & lac 'è/ik' & berēk'/ik' & sirec ' $^{\prime} / i k$ ' & t'otē/ik' \\
\hline $3 \mathrm{pl}$. & lac in & berin & sirec'in & t'otin \\
\hline
\end{tabular}

\section{Spread of $e$ -}

In a number of inscriptions one observes a spread of $e$-: 3 pl. $e$ $t^{\prime}$ 'otin (Vayoc' Jor, the village of $\mathrm{T}^{\prime} \mathrm{erp}^{\prime}, 1264 \mathrm{CE}$ ) instead of t'otin (CArm. t'olum 'to let, leave', cf. $3 \mathrm{sg}$. e-t'ot); 3 pl. e-barj-in in Ani instead of barjin (CArm. barnam < *barj-nam 'to lift, raise', cf. $3 \mathrm{sg} . e-$ barj), etc. This is observable even in $c$ '-forms the corresponding Classical paradigms of which never had an $e^{-}$. Here are examples from

${ }^{1}$ I am greatly indebted to Kate Bellamy for checking my English. I am also indebted to Rémy Viredaz, Nikolai Kazansky, and Petr Kocharov for making a few corrections. 
the Lori and Tavuš regions, the $13^{\text {th }}$ century: $\bar{e}$-gnec ' $i$ 'I bought' (Sanahin and Enok'avan); e/e-grec 'in 'they wrote' (Ōjun and Makaravank'). One also finds examples that combine the Middle Armenian forms with Classical ones, such as e-tui (vs. CArm. etu and MArm. $t u-i$ ), the $1 \mathrm{sg}$.aor. of tam 'to give' (Ani, Makaravank', etc.; the $11^{\text {th }}$ century onwards); cf. 1 pl. e-tua(n)k'vs. CArm. and MArm. tuak'.

S. Avagyan [1986: 134-142] discusses the material and concludes that the vowel $e$ - of these forms is due to insufficient grammar skills of the authors of these inscriptions. However, there is dialectal evidence pointing to the fact that at least in some cases we may be dealing with really existent forms. In $\S 6$, the examples of etui and etuak' will be discussed in greater detail.

\section{First person plural imperfect}

The Classical Armenian 1 pl. imperfect ending is characterized by the presence of a vowel $-a$-; thus, for example, in the $e$-conjugation we have the following set of endings: $-\bar{e} i,-\bar{e} i r,-\bar{e} r,-\bar{e} a k^{\prime},-\bar{e} i k^{\prime},-\bar{e} i n$. In Modern Armenian and most of dialects, this $-a$ - has been analogically eliminated, but some dialects have preserved it intact. In the Tables 2-3, I present the Classical imperfect paradigm of the verb utem 'to eat' and its corresponding tense forms (imperfect or past subjunctive) in the dialects of Akn [Ačaryan 1911:223] (cf. ibid., p. 227 on Sebastia), Hamšen [Ačaryan 1947: 136, 139], and SEA. I also include two paradigms from the region of Dersim, grem 'to write' in Xarberd/Erznka, and $k$ 'ašem 'to pull, drag' in Č'mškacag [Bałramyan 1960: 22, 30]; the latter preserves the $-a$ - intact whereas the former is innovative. Interestingly, the forms that are characterized by the archaic - $a$ - show innovations too; in Hamšen we see analogical insertion of $-i / y$-, whereas the others have the innovative nasal.

Table 2. The imperfect paradigm of the verb 'to eat' in Classical Armenian, the dialects of Akn, Hamšen, and Standard Eastern Armenian

\begin{tabular}{|c|c|c|c|c|}
\hline & CArm. & Akn & Hamšen & SEA \\
\hline & utēi & $g$-üdci & g-udcyə & $k$-utei \\
\hline & utēir & $g$-üdcir & $g-u d \varepsilon y d(\partial)$ & $k$-uteir \\
\hline & $u t \bar{e} r$ & $g-\ddot{u} d \varepsilon r$ & $g-u d \varepsilon r$ & $k$-uter \\
\hline & $u t \bar{e} \boldsymbol{a} k^{\prime}$ & g-üdcank“ & g-udayk's & k-uteink' \\
\hline & utēik' & $g$-üdcik‘ & $g$-udzyk'ə & k-uteik‘ \\
\hline & utèin & $g$-üdcin & g-udвуnə & $k$-utein \\
\hline
\end{tabular}


Table 3. The imperfect paradigm of the verbs 'to pull' in the dialect of Č'mškacag and 'to write' in the dialect of Xarberd/Erznka

\section{Č'mškacag Xarberd/Erznka}

$1 \mathrm{sg}$. ga k'ašci ga g'arci

$2 \mathrm{sg}$. ga k'ašeir ga g'arcir

$3 \mathrm{sg}$. ga k'ašer ga g'arer

1 pl. ga k'ašcank' ga g'arcink ${ }^{c y}$

2 pl. ga 'ašcik' ga g'arcik'

3 pl. ga k'ašzin ga g'arદin

\section{First person plural aorist and the $e$ - augment}

As we have seen in Section 1, the same 1 pl. $-a$ - is seen in the aorist of Classical Armenian. Here again, some dialects preserve it intact, cf. e.g. the paradigms of xatam 'to play' and sirem 'to love' in Hamšen [Ačaryan 1947: 128, 131].

Table 4. The aorist paradigm of the verbs xatam 'to play' and sirem 'to love' in Classical Armenian

\begin{tabular}{|c|c|c|}
\hline & xatam & sirem \\
\hline & 'to play' & 'to love' \\
\hline $1 \mathrm{sg}$. & $x^{\prime a t a c} i$ & $\operatorname{sircc}^{\prime} i$ \\
\hline $2 \mathrm{sg}$. & xałac ir & sirec 'ir \\
\hline $3 \mathrm{sg}$. & xatac" & sirec \\
\hline 1 pl. & xałac'ak' & $\operatorname{sircc}^{\prime} \boldsymbol{a} \boldsymbol{k}^{\prime}$ \\
\hline 2 pl. & xałac'ik' & $\operatorname{sircc}^{\prime} i k^{\prime}$ \\
\hline 3 pl. & xałac'in & sirec in $^{\prime}$ \\
\hline
\end{tabular}

In old monosyllabic aorist forms of this dialect we find yet another archaism, the augment $e^{-}$. Here is the example of banam, aor. stem bac'- 'to open' [Ačaryan 1947: 135].

Table 5. The aorist paradigm of the verbs 'to open' in Classical Armenian and the Hamšen dialect

CArm. act. CArm. med. Hamšen

$\begin{array}{llll}1 \mathrm{sg} . & b a c^{\prime} i & b a c^{\prime} a y & p a c^{\prime} i \\ 2 \mathrm{sg} . & \text { bac'er } & \text { bac'ar } & \text { pac'ir } \\ 3 \mathrm{sg} . & \boldsymbol{e}-b a c^{\prime} & \text { bac'aw } & \text { pac'aw, } \boldsymbol{\varepsilon}-p a c^{\prime}\end{array}$

${ }^{2}$ For a discussion of this Hamšen archaism, see [Vaux 2007: 265-266]. It is also present in a neighboring dialect of Xotorjur [Kostandyan 1985: 60]. 
CArm. act. CArm. med. Hamšen

$1 \mathrm{pl}$. bac'ak' bac'ak' pac'ak'

2 pl. bac'ék', -ik' bac'ayk' pac'ik'

3 pl. bac'in bac'an pac'in

\section{Hamšen asuš, aor. stem ast- 'to say'}

CArm. asem 'to say, tell, speak' displays aorist forms based on ast- in Hamšen. According to Ačaryan [1947: 134-135], the -t- after $-s$ - is an epenthesis of a phonetic nature, cf. almas 'diamond'> almast, $t$ 'asel 'to puff' $>t$ 'astuš, etc. This explanation is not entirely satisfactory because: 1) it is not clear why the $-t$ - is only found in the aorist; 2) we expect to see the reflexes of the aoristic $c^{6}$-. I therefore propose the following solution.

In Classical Armenian, the aorist stem of this verb is asac"-. This subtype displays both non-syncopated and syncopated aorist forms in Hamšen, namely xałac ' $i$ and xatc' $i$ (see [Ačaryan 1947: 130131]). It seems therefore likely that Hamšen asti etc. derive from the syncopated forms *asc' $i$ etc.; the development ${ }^{*} a s c$ ' $i>a s t i$ is probably due to dissimilation, which may have been triggered or reinforced by the aforementioned $-(s) t$ - epenthesis. For the inclusion of the $3 \mathrm{sg}$. aor. med. into the main paradigm, compare the aforementioned pac'aw alongside $\varepsilon$-pac' (cf. MArm. 1sg. gtay vs. CArm. 1sg. gti 'I found', see Karst 1901: 327).

In the Table 6, I have combined the Classical and Hamšen paradigms with that of Šamaxi $/ \mathrm{K}^{\text {'y }}$ ärk ${ }^{\text {' }}$ änǰ, an easternmost dialect (on which see [Bałramyan 1964: 166]):

Table 6. The aorist paradigm of the verbs 'to say' in Classical Armenian and

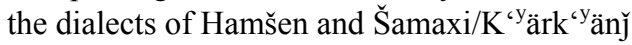

\section{CArm.}

$1 \mathrm{sg}$. asac' $i$

$2 \mathrm{sg}$. asac'er

$3 \mathrm{sg}$. asac"

$1 \mathrm{pl}$. asac' $a k^{\prime}$

$2 \mathrm{pl} . \quad$ asac '$^{\prime} \bar{k}$ ', $-i k$ '

$3 \mathrm{pl}$. asac'in
Syncope

*asc' $i$

*asc'er

*as $(a) c^{6}$-aw (med.)

*asc'ak'

${ }^{*} a s c$ ' $\bar{e} k^{\prime},-i k$ '

*asc'in
Hamšen

as- $t-i$

as-t-ir

as-t-av

$a s-t-a k^{\prime}$

as-t-ik'

as-t-in
Šamaxi asc ' $i$, assi asc 'ir, assir asec', asec asc 'ink', assink' asc 'ik', assik' asc'in, assin 


\section{The aorist forms of tam 'to give' in Aramo and other dialects}

In Classical Armenian, the irregular verb tam 'to give' is characterized by the $e$-augment throughout the paradigm except for $1 \mathrm{pl}$. and the absence of the vowel i/e/e in $1 \mathrm{sg}$., $2 \mathrm{sg}$., $2 \mathrm{pl}$., and $3 \mathrm{pl}$. In Middle Armenian (see Karst 1901: 333), dialects and modern Armenian one finds analogical developments:

1) the root $* t u$ is recovered in the $3 \mathrm{sg}$. form: $e t \rightarrow e t u$;

2 ) the augment $e$ - is eliminated from the paradigm but in some dialects it is preserved in the $3 \mathrm{sg}$. form;

3 ) the regular endings are added to this new basis: $e t u \rightarrow t u-i$, etur $\rightarrow$ tu-i-r, etc.

The vowel $-a$ - in $1 \mathrm{pl}$. forms and the augment $e$ - are both present in the Aramo dialect, where, for example, advunk' reflects $* e$ tuank' and stands for the CArm. tuak', 1 pl. aorist of the verb tam 'to give'. In what follows I shall discuss this remarkable case in more detail since it simultaneously represents an illustrative combination of archaisms and innovations.

The Classical Armenian aorist forms etu, etur, and et, have been replaced in Aramo by adva, advey, and ida respectively. Łaribyan [1958: 47] (cf. ibid., pp. 19, 21) derives 3 sg. aorist ida from *etu (for the vocalic reflections, cf. ere/ikun 'evening' > irgäun, katu 'cat' > gada, heru 'last year' > hira, heru 'far' > hərira, etc.) but gives no explanations for the other forms. The Classical $3 \mathrm{sg}$. form et was thus replaced by *etu, and all the other personal forms, as we shall see, have been reshaped by attaching the regular set of aorist endings to this base *etu.

The $1 \mathrm{sg}$. aor. form adva may reflect $* e t u$ - $i$, in which the ending $-i$ is taken from the Classical aorist ending $-i$. The vocalic developments are regular: 1) $e^{-}>\partial_{-}$, cf. ezr 'edge' $>$ozzir $(\ddot{a})$, erek' 'three' $>$ ark', erkir 'earth' > argayr; 2) word-final $-i>-a$, cf. agi 'tail' >akka, aygi 'garden' > skka, oski 'gold'> $>$ ska, etc. (see [Łaribyan 1958: 19, 20]). The existence of such an analogical form is confirmed by some inscriptional evidence from the $11^{\text {th }}$ century onwards, étvi (Ani, 1058 CE) and ètui (Makaravank's).

\footnotetext{
${ }^{3}$ See [Ōrbeli et. al. (eds.) 1960: 13, Nr 51; Avagyan 1986: 136-137].
} 
The $2 \mathrm{sg}$. aor. form $\partial d v \varepsilon y$ in all probability reflects an analogical *etu-er, with the CArm. 2 sg. aor. ending -er (cf. gišer 'night' > $k i s ̌ \varepsilon y r$, ver 'up, above' $>v \varepsilon y r$, etc.). As to the alternation $-\varepsilon y$ vs. $-\varepsilon(y) r$, compare the $1 \mathrm{sg}$. pres. perf. forms: affirmative adver im vs. negative č'วm idvey. See below on the contrast between the archaic -er in Aramo and Svedia on the one hand and the innovative -ir (seen in Middle and Modern Armenian) in Zeyt' un on the other hand.

The 1 pl. aor. form advunk ' reflects *e-tuank' according to regular sound laws (cf. aprank'> abrunk', p'orjank'>p'src'unk'), and $2 \mathrm{pl}$. and 3 pl. forms derive from *etu-ik' and *etu-in respectively (cf. cic $>$ jäyj, hing $>$ häyng), analogically acquiring thus the corresponding Classical endings $-i k$ ' and -in. The existence of 3 pl. aor. *etuank' is confirmed by, for example, an inscription from the Šxmurat monastery (Tavuš, the village of Całkavan) in $1248 \mathrm{CE}$, which has the form êtvank'; cf. three earlier attestations $\left(12^{\text {th }}\right.$ and early $13^{\text {th }}$ centuries $)$ from the same regions with no nasal - etuak', ètuak', and êtvak' [Avagyan 1986: 136].

In the tables below, I have combined these paradigms with those of Middle Armenian [Karst 1901: 333 (= 2002: 315-316); Ant'osyan 1975: 213; Hovsep'yan 1997: 68-69], Modern Western and Eastern Armenian [Ant'osyan 1975: 214], and the following dialects:

1) Western grouping: Svedia in Syria [Ačaryan 2003: 494, 498], Zeyt'un in Cilicia [Ačaryan 2003: 243], Hamšen in the NorthWestern intergroup [Ačaryan 1947: 137], Muš in the South-Central group [Bałdasaryan-T'ap'alc'yan 1958: 169] and neighboring Sasun [Petoyan 1954: 59], Polis/Constantinople [Ačaryan 1941: 149], Moks [Muradyan 1982: 173]; cf. Šatax, see [Muradyan 1962: 148], $1 \mathrm{sg}$. təvi), Van [Ačaryan 1952: 173];

2) Eastern grouping: Marała [Ačarean 1926: 262], Agulis [Ačarean 1935: 260], Šamaxi [Bałramyan 1964: 129, 162, 167], Kṙen [Bałramyan 1961: 151], Hadrut' [Połosyan 1965: 212], Ararat/Lori [Asatryan 1968: 141]. Brief outlines of individual dialects and dialectal maps can be found in [Martirosyan 2013].

Table 7. The paradigm of the verb 'to give' in Classical Armenian, the dialect of Amaro, inscriptions, and the Modern Armenian
CArm. Aramo
$1 \mathrm{sg}$. etu
adva
Proto-Aramo
2 sg. etur
advey
*etu-i
Inscriptions $\left(11^{\text {th }}\right.$ cent. +$)$
$3 \mathrm{sg}$. et
$i d a$
ètvi, ètui
*etu-e(r)
*etu


CArm. Aramo Proto-Aramo Inscriptions $\left(11^{\text {th }}\right.$ cent. + )

1 pl. tuak' advunk' *etua(n)k' elētuak', étvank'

$2 \mathrm{pl}$. etuk' adväk' *etu-ik'

3 pl. etun adväyn ${ }^{4}$ *etu-in

MArm. SWA SEA

$1 \mathrm{sg} . \quad t u-i \quad t u-i \quad t v\left(e c^{\prime}\right) i$

$2 \mathrm{sg}$. tu-ir tu-ir tv(ec')ir

3 sg. etu-r, eret, tu-aw tu-aw tvec"

$1 \mathrm{pl}$. tuak' tu-ink' tv(ec')ink'

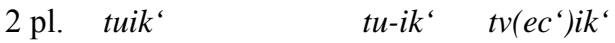

3 pl. tuin tu-in tv(ec')in

Table 8. The paradigm of the verb 'to give' in the Western grouping of the dialects

\begin{tabular}{|c|c|c|c|c|c|}
\hline $1 \mathrm{sg}$. & $\begin{array}{l}\text { Svedia } \\
d v a\end{array}$ & $\begin{array}{l}\text { Pr.-Sved. } \\
* t u-i\end{array}$ & $\begin{array}{l}\text { Zeyt'un } \\
d e v e\end{array}$ & $\begin{array}{l}\text { Pr.- Zeyt }{ }^{6} . \\
*_{t u-i}\end{array}$ & $\begin{array}{l}\text { Hamšen } \\
d v i\end{array}$ \\
\hline $\mathrm{sg}$ & $d v i r$ & $* t u-e r$ & devey & $*_{t u-i r}$ & $d v i r$ \\
\hline sg & $i$-d $\ddot{o r} r$ & $* e-t u-r$ & dวvวv & $* t u-a w$ & $d v a v$, cred \\
\hline pl. & dvunk' & $* t u$-ank & dovonk" & $*_{t u-a n k}$ & dvak' \\
\hline pl. & $d v \ddot{a} k^{\prime}$ & $* t u-i k^{*}$ & devek' & $* t u-i k^{\prime}$ & $d v i k^{\prime}$ \\
\hline pl. & $d v \varepsilon n$ & $* t u$-in & deven & $* t u-i n$ & $d v i n$ \\
\hline
\end{tabular}

\begin{tabular}{|c|c|c|c|c|c|}
\hline & Muš & Sasun & Polis & Moks & Van \\
\hline $1 \mathrm{sg}$. & $\operatorname{t\partial v}\left(\varepsilon c^{\prime}\right) i$ & $d v \ddot{a} c^{\prime} \partial$ & $d u v i$ & tava & $t v\left(i c^{\prime}\right) i$ \\
\hline S & $\operatorname{t\partial v}\left(\varepsilon c^{\prime}\right) i r$ & $d v a ̈ c^{\prime} \partial r$ & duvir & tavir & $t v\left(i c^{\prime}\right) i r$ \\
\hline$s$ & tovec & $d v a c^{*}$ & duvav & $i-t u$ & tvec', $\boldsymbol{i}$-tu(r) \\
\hline & $\operatorname{tav}\left(\varepsilon c^{\prime}\right) \operatorname{in} k^{\prime}$ & $d v \ddot{a} c^{\prime} \partial k^{\prime}(!)$ & duvink" & tavink $k^{c y}$ & $t v\left(i c^{\prime}\right) i n k^{c y}$ \\
\hline & $\operatorname{tav}\left(\varepsilon c^{\prime}\right) i k^{\prime}$ & $d v \ddot{a} c^{\prime} \partial k^{\prime}$ & duvik' & tovik & $t v\left(i c^{\prime}\right) i k^{y}$ \\
\hline & $\operatorname{t\partial v}\left(\varepsilon c^{\prime}\right) i n$ & $d v \ddot{a} c^{\prime} \partial n$ & duvin & tavin & $t v\left(i c^{\prime}\right)$ in \\
\hline
\end{tabular}

Table 9. The paradigm of the verb 'to give' in the Eastern grouping of the dialects

$\begin{array}{llll} & \text { Marała } & \text { Agulis } & \text { Šamaxi } \\ 1 \mathrm{sg} . & \text { tuv/rum } & \text { tvem } & \text { tur/vi } \\ 2 \mathrm{sg} . & \text { tuv/rir } & \text { tves } & \text { tur/vir } \\ 3 \mathrm{sg} . & \text { tuv/ric" } & - & \text { u-tur, tur/vav }\end{array}$

${ }^{4}$ Printed as anväyn in [Łaribyan 1958: 47]; probably a misprint. 


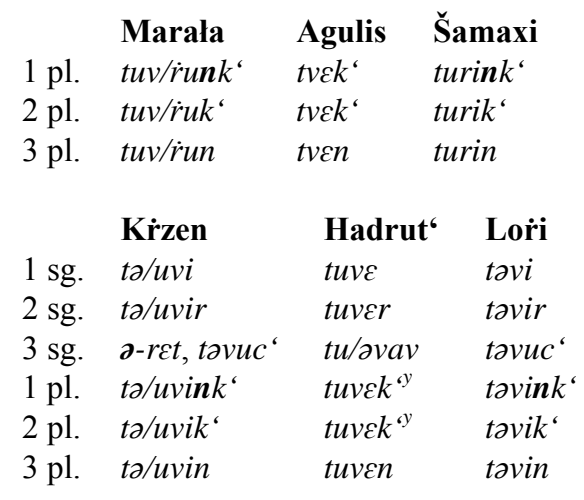

Notes:

1) For Zeyt'un deve < *tui, cf. neveg < nuik 'arum lily' [Ačaryan 2003: 60, 331].

2) All the phonological developments of the vowel $i$ in $1 \mathrm{sg}$. (-i $>-a), 2 \mathrm{pl} .\left(-i k^{\prime}>-\ddot{a} k^{\prime}\right)$ and $3 \mathrm{pl}$. (-in $\left.>-\varepsilon n\right)$ are regular in Svedia. As for $2 \mathrm{sg}$. dvir, it goes back to *tu-er rather than *tu-ir, cf. gišer 'night' $>g$ 'išir, sisern 'chick-pea' > sisir on the one hand, and karmir 'red' > $g^{y}$ ärmer, moxir 'ash' $>$ mäxxer on the other. For the material, see [Ačaryan 2003: 370-374, 377-383].

3) Agulis has no $3 \mathrm{sg}$. aor. in general [Ačarean 1935: 267]. According to Ačaryan [1935: 145-146, 243], Agulis 1 pl. aor. - $V k^{\prime}$ comes from $-V n k$ ' through the loss of the nasal. This is not necessarily the case.

\section{Conclusion}

Various analogical developments have taken place in dialects; some peripheral dialects preserve archaic features. One finds more than one line of developments from Classical Armenian to modern dialects (not always through Middle Armenian). Inscriptions from North-East of historical Armenia in the $11^{\text {th }}$ century onwards deviate from Middle Armenian but correspond to a dialectal development in Aramo (Syria), the farthest and most isolated dialect in the South-West corner.

\section{Abbreviations}

CArm. - Classical Armenian; MArm. - Middle Armenian; SEA — Standard Eastern Armenian; SWA — Standard Western Armenian. 


\section{Bibliography}

Ačaryan 1911 - Hr. H. Ačaryan. Hay barbaragitut' iwn: uruagic ew dasaworut'iwn hay barbarneri (barbaragitakan k'artēsov) // Эминский этнографический сборник. Т. 8. М.: Лазаревский Институт Восточных языков, 1911.

Ačaryan 1913 - Hr. H. Ačaryan. Hayerēn gawarakan bararan // Эминский этнографический сборник. Т. 9. Тифлис: Лазаревский Институт Восточных языков, 1913.

Ačaryan 1926 - Hr. H. Ačaryan. K'nnut'iwn Marałayi barbarii. Yerevan: EPH hratarakč'ut'yun, 1926.

Ačaryan 1935 - Hr. H. Ačaryan. K'nnut'iwn Agulisi barbarii. Yerevan: Pethrat, 1935.

Ačaryan 1941 - Hr. H. Ačaryan. K'nnut'yun Polsahay barbari // Gitakan ašxatut'yunner 19, 1941. P. 19-250.

Ačaryan 1947 - Hr. H. Ačaryan. K'nnut'yun Hamšeni barbarì. Yerevan: HSSR GA hratarakč 'ut'yun, 1947.

Ačaryan 1952 - Hr. H. Ačaryan. K'nnut'yun Vani barbarì. Yerevan: EPH hratarakč 'ut'yun, 1952.

Ačaryan 2003 - Hr. H. Ačaryan. K'nnut'yun Kilikiayi barbarii. Yerevan: EPH hratarakč'ut'yun, 2003.

Ant'osyan 1975 - S. M. Ant'osyan. Xonarhman hamakargi zargac'man ənt'ac'k'ə// L.S. Hovsep'yan (ed.), Hayoc' lezvi patmakan k'erakanut'yun. Vol. 2. Yerevan: HSSH GA hratarakč'ut'yun. P. 159-377.

Asatryan 1968 - M. E. Asatryan. Loru xosvack‘ə. Yerevan: EPH hratarakč'ut'yun, 1968.

Avagyan 1986 - S. A. Avagyan. Vimagrakan prptumner. Yerevan: EPH hratarakč'ut'yun, 1986.

Bałdasaryan-T'ap'alc'yan 1958 - S. H. Bałdasaryan-T'ap'alc'yan. Mšo barbarə. Yerevan: HSSRं GA hratarakč‘ ut'yun, 1958.

Bałramyan $1960-\dot{\mathrm{R}}$. H. Bałramyan. Dersimi barbarayin k'artezə. Yerevan: HSSR GA hratarakč ‘ut'yun, 1960.

Bałramyan 1961 - $\dot{R}$. H. Bałramyan. Kṙzeni barbaṙ. Yerevan: HSSR GA hratarakč'ut'yun, 1961.

Bałramyan $1964-\dot{R}$. H. Bałramyan. Šamaxii barbaṙ. Yerevan: HSSH GA hratarakč'ut'yun, 1964.

Hovsep 'yan 1997 — L. S. Hovsep'yan. ŽG dari hayeren jeragreri hišatakaranneri lezun. Yerevan: Van Aryan, 1997.

Karst 1901 - J. Karst. Historische Grammatik des Kilikisch-Armenischen. Strassburg: Verlag von Karl J. Trübner, 1901. 
Karst 2002 - J. Karst. Kilikyan hayereni patmakan k'erakanut'yun (Modern Armenian translation from Karst 1901 by D. Alivnyak). Yerevan: EPH hratarakč‘ ut'yun, 2002.

Kostandyan 1985 - D. M. Kostandyan. Xotrjuri barbarayin yurahatkut'yunneri lezvaašxarhagrakan bnut'agirə // H. D. Muradyan (ed.). Hayereni barbaragitakan atlas: usumnasirut'yunner ew nyut'er. Vol. 2. Yerevan: HSSH GA hratarakč'ut'yun, 1985. P. 46-68.

Łaribyan 1958 - A. S. Łaribyan. Hayereni norahayt barbarneri mi nor xumb. Erevan: HSSR GA hratarakč‘ ut'yun, 1958.

Martirosyan 2013 - Г. К. Мартиросян. Армянские диалекты: характеристика отдельных диалектов // Ю. Б. Коряков, А. А. Кибрик. (ред.). Языки мира. Реликтовые индоевропейские языки Передней и Центральной Азии. М.: Academia, 2013. С. 334-385. [H. Martirosyan. Armianskie dialekty: kharakteristika otdel'nykh dialektov // Iu. B. Koriakov, A. A. Kibrik. (ed.). Iazyki mira. Reliktovye indoevropeiskie iazyki Perednei i Tsentral'noi Azii [Languages of the World: Relict Indo-European Languages of Western and Central Asia]. M: Academia, 2013: P. 334-385].

Muradyan 1962 - M. H. Muradyan. Šataxi barbarə. Yerevan: EPH hratarakč'ut'yun, 1962.

Muradyan 1982 - M. H. Muradyan. Urvagic Moksi barbari // H. D. Muradyan (ed.). Hayereni barbaragitakan atlas: usumnasirut'yunner ew nyut'er.

Vol. 1. Yerevan: HSSH GA hratarakč'ut'yun, 1982. P. 108-183.

Ōrbeli et. al. (eds.) 1960-... - H. Ōrbeli, S. G. Barxudaryan et al. (eds.). Divan hay vimagrut'yan. Yerevan: HSSR GA hratarakč'ut'yun, 1960-...

Petoyan 1954 - V. A. Petoyan. Sasuni barbarə. Yerevan: HSSH GA hratarakč'ut'yun, 1954.

Połosyan 1965 - A. M. Połosyan. Hadrut'i barbaṙ. Yerevan: HSSH GA hratarakč'ut'yun, 1965.

Vaux 2007 - B. Vaux. Homshetsma: the language of the Armenians of Hamshen // H. H. Simonian (ed.). The Hemshin: history, society and identity in the Highlands of Northeast Turkey. London - New York: Routledge, 2007. P. 257-278. 